\title{
The La (SS-B) autoantigen, a key protein in RNA biogenesis, is dephosphorylated and cleaved early during apoptosis
}

\author{
Saskia A Rutjes ${ }^{1}$, Paul J Utz ${ }^{2}$, Annemarie van der Heijden', \\ Christel Broekhuis ${ }^{1}$, Walther $\mathrm{J}$ van Venrooij ${ }^{1}$ and \\ Ger JM Pruijn*,1 \\ 1 Department of Biochemistry, University of Nijmegen, P0 Box 9101, NL-6500 \\ HB Nijmegen, The Netherlands \\ 2 Department of Medicine, Division of Rheumatology, Immunology, and Allergy, \\ Brigham \& Women's Hospital, Boston, Massachusetts, MA 02115, USA \\ * corresponding author: Ger JM Pruijn, Department of Biochemistry, University \\ of Nijmegen, P0 Box 9101, NL-6500 HB Nijmegen, The Netherlands. \\ tel: (+31) 24361 6847; fax: (+31) 243540525
}

Received 29.3.99; revised 1.7.99; accepted 20.7.99

Edited by $\mathrm{G}$ Salvesen

\begin{abstract}
In the past few years, a role for apoptotic processes in the development of autoimmune diseases has been suggested. An increasing number of cellular proteins, which are modified during apoptosis, has been described, and many of these proteins have been identified as autoantigens. We have studied the effects of apoptosis on the La protein in more detail and for the first time demonstrate that this autoantigen is rapidly dephosphorylated after the induction of apoptosis. Dephosphorylation of the La protein was observed after induction of apoptosis by several initiators and in various cell types. Furthermore, we demonstrate that at least a subset of the La protein is proteolytically cleaved in vivo, generating a $45 \mathrm{kDa}$ fragment. Dephosphorylation as well as cleavage of $\mathrm{La}$ is inhibited by $\mathrm{ZnSO}_{4}$ as well as by several tetrapeptide caspase inhibitors, indicating that these processes require the activation of caspases. Dephosphorylation of $\mathrm{La}$ is inhibited by low concentrations of okadaic acid, suggesting that a PP2A-like phosphatase is involved. Generation of the $45 \mathrm{kDa}$ fragment is consistent with proteolytic cleavage at amino acids 371 and/or 374 . The possible significance of the apoptotic changes in the La protein for autoantibody production is discussed.
\end{abstract}

Keywords: apoptosis; autoimmunity; caspase cleavage; dephosphorylation; La (SS-B)

Abbreviations: Ac, acetyl; CMK, chloromethylketone; DMSO, dimethyl sulfoxide; DTE, dithioerythritol; EDTA, ethylenediaminetetraacetic acid; FITC, fluorescein isothiocyanate; FMK, fluoromethylketone; NLS, nuclear localization signal; NP-40, Nonidet P40; PAGE, polyacrylamide gel electrophoresis; PI, propidium iodide; pol III, RNA polymerase III; PP2A, protein phosphatase 2A; SDS, sodium dodecyl sulfate; SLE, systemic lupus erythematosus; SS, Sjögren's syndrome; uH2A, ubiquitinated histone $\mathrm{H} 2 \mathrm{~A} ; \mathrm{Z}$, carbobenzoxy

\section{Introduction}

In the past few years, a role for apoptosis in the development of autoimmune diseases has been suggested. ${ }^{1,2}$ Apoptosis is characterized by typical morphological changes in the dying cell, including chromatin condensation and membrane blebbing. Such manifestations are induced by biochemical modifications of nuclear and cytoplasmic proteins. An increasing number of cellular proteins which are cleaved during apoptosis have been described. Some of these proteins are structural proteins essential for maintaining nuclear and cytoplasmic architecture, while others are enzymes essential for repairing damaged cell components. Cleavage of these proteins, which is mediated by cysteine-proteases that are specifically activated during apoptosis (caspases) ${ }^{3}$ results in the irreversible changes associated with apoptosis. Many of these cleaved proteins have been identified as autoantigens and include the $U 1-70 \mathrm{~K}$ protein, which is a component of the U1 snRNP particle; ${ }^{4}$ poly(ADP-ribose) polymerase (PARP); ${ }^{5}$ hnRNP proteins $\mathrm{C} 1$ and $\mathrm{C} 2{ }^{6}{ }^{6}$ and $\alpha$ fodrin. ${ }^{7}$ It has been postulated that cleavage of these proteins might unmask cryptic epitopes which are then presented to the immune system in such a way that tolerance to self proteins is broken (reviewed by Utz and Anderson). ${ }^{8}$ Another mechanism by which proteins are fragmented, possibly resulting in the creation of novel epitopes, is via reactive oxygen radicals. Several autoantigens that are targeted in scleroderma (e.g., topoisomerase I, the large subunit of RNA polymerase II, and NOR 90) are uniquely susceptible to cleavage by reactive oxygen species in the presence of metal ions. ${ }^{9}$

Four other types of posttranslational modifications which occur during apoptosis and which might lead to the generation of autoantibodies have been described. First, apoptotic hyperphosphorylation has been observed for U1 snRNP-associated serine/arginine family of splicing factors (SR proteins). ${ }^{10}$ Phosphorylation may also play a role in autoantigenicity of RNA polymerase I and pol II components, which are only recognized by autoantibodies from SLE patients when they are phosphorylated. ${ }^{11,12}$ Second, at least four autoantigens (histone H2B, actin, tubulin and troponin) are substrates for tissue transglutaminase, which is activated during apoptosis and which catalyzes the cross-linking of its substrate proteins. ${ }^{13}$ Third, ubiquitinated histone $\mathrm{H} 2 \mathrm{~A}$ ( $\mathrm{uH} 2 \mathrm{~A}$ ) has been described in normal cells but is absent in cells undergoing apoptosis induced by TGF $\beta 1$, suggesting that the ubiquitin conjugating apparatus responsible for maintaining $\mathrm{uH} 2 \mathrm{~A}$ is disrupted during apoptosis. ${ }^{14,15}$ Fourth, a variety of nuclear proteins have been described to undergo extensive poly(ADP-ribosyl)ation early during apoptosis. ${ }^{16,17}$ Each of these modifications may create novel epitopes or increase the half-life of proteins present 
in apoptotic cells, leading to changes in the exposure of these modified antigens to the immune system (reviewed by Utz and Anderson). ${ }^{8}$ Although no other autoantigen modifications have so far been reported to occur during apoptosis, citrullination, methylation, deacetylation and dephosphorylation are modifications which may also contribute to the antigenicity of modified proteins.

One of the best studied autoantigens targeted in systemic lupus erythematosus (SLE) and Sjögren's syndrome (SS) is the La (SS-B) protein. La is an evolutionarily conserved phosphoprotein of $50 \mathrm{kDa}$, which under normal conditions accumulates in the nucleus. The La protein has been shown to bind, in most cases transiently, to all newly synthesized RNA polymerase III (pol III) transcripts and is involved in transcription of these RNAs. ${ }^{18}$ La is necessary for correct and efficient termination of pol III transcription ${ }^{19,20}$ and has recently been identified as a pol III initiation factor. ${ }^{21,22}$ Phosphorylation of serine-366 has been shown to play an essential role in this process since La phosphorylated at this position appears to be transcriptionally inactive whereas dephosphorylated $\mathrm{La}$ is active. ${ }^{23}$ However, a specific function for La in pol III transcription has recently been questioned by the results of in vitro transcription experiments in a Xenopus laevis system. ${ }^{24}$ La plays a role in RNA processing of pol III transcripts as has been shown for tRNA $3^{\prime}$ - and $5^{\prime}$-end maturation. ${ }^{25-27} \mathrm{La}$ also appears to play an important role in internal initiation of translation ${ }^{28,29}$ and has been found associated with the $5^{\prime}$ UTR of several mRNAs. ${ }^{30-32}$ Finally, an RNA chaperone activity for La, which might be consistent with all of its reported activities, has recently been proposed. ${ }^{24,25}$

It has been described previously that the subcellular localization of the La protein in human keratinocytes is altered after induction of apoptosis by UV irradiation. ${ }^{1}$ In this study, the La protein appeared to be present in DNAcontaining apoptotic bodies, together with the ribonucleoprotein antigen Ro and the $U$ snRNA-containing small nuclear RNPs. The involvement of the La protein in a large variety of biosynthetic processes makes this protein an attractive target for inactivation during early stages of apoptosis. Although acidic degradation of La generating a $43 \mathrm{kD}$ cleavage product occurring in apoptotic as well as in non-apoptotic cell lysates has been described, ${ }^{33}$ no changes specifically occurring during apoptosis have been reported for the La protein. In view of the functional relevance of the phosphorylation of $\mathrm{La}$ and the frequently observed cleavage of many (autoantigenic) proteins during apoptosis, we investigated these modifications for the La autoantigen in apoptotic cells. We demonstrate that the $\mathrm{La}$ protein is completely dephosphorylated upon exposure of the cells to multiple apoptotic stimuli. Dephosphorylation of La is inhibited by low concentrations of okadaic acid, suggesting that a PP2A-like phosphatase activity is involved. Furthermore, we demonstrate that at least a subset of the La protein is proteolytically cleaved. Dephosphorylation as well as cleavage of $\mathrm{La}$ is inhibited by Bcl-2, zinc and several tetrapeptide caspase inhibitors, suggesting that caspases are involved in these processes. Based upon their nature and position the molecular changes of the $\mathrm{La}$ protein reported in this study are likely to interfere with the biological function and subcellular distribution of this protein.

\section{Results}

Increasing evidence has been obtained demonstrating a relationship between apoptosis and the induction of autoimmunity. One of the main autoantigens recognized by sera of patients with systemic lupus erythematosus and Sjögren's syndrome is the La (SS-B) protein. Previously it has been reported that the La protein is relocalized to apoptotic bodies where it colocalizes with fragmented DNA. ${ }^{1}$ To study the potential molecular changes in the La protein during apoptosis we used two stably transfected Jurkat cell lines, one overexpressing the apoptosis inhibitor Bcl-2 (Jurkat/Bcl-2) and the second a transfection vector control line (Jurkat/Neo). To induce apoptosis, the cells were treated with the monoclonal antibody $7 \mathrm{C} 11$, which cross-links and activates Fas.

\section{The La (SS-B) autoantigen is dephosphorylated and cleaved early during apoptosis}

The phosphorylation state of the La protein is of major importance for its function in the coordination of transcriptional and early post-transcriptional stages of pol III RNA biogenesis, which is mediated by a phosphorylation/dephosphorylation cycle. To study potential changes in the phosphorylation of the La protein during apoptosis, Jurkat cells were metabolically ${ }^{32} \mathrm{P}$-labeled and treated with antiFas antibody. Cell extracts were prepared at various timepoints. The phosphorylation state of the La protein in these extracts was determined by immunoprecipitation of La from ${ }^{32} \mathrm{P}$-labeled cell extracts using a monoclonal anti-La antibody (SW5) followed by SDS-PAGE and Western blot analysis of the immunoprecipitate. Labeled proteins were detected by autoradiography. Analysis of the anti-La immunoprecipitate from the radiolabeled cell extracts revealed that during early stages of apoptosis the $\mathrm{La}$ protein was efficiently dephosphorylated (Figure 1A). Quantification of phosphorylated La using a phosphorimager demonstrates that within $2 \mathrm{~h}$ after anti-Fas treatment more than $50 \%$ of the radiolabeled phosphate was removed from the La protein in Jurkat/Neo cells. Although dephosphorylation was also observed in the Jurkat/Bcl-2 cells, the rate of dephosphorylation in these cells was much lower than that in the Jurkat/Neo cells (Figure 1A, compare lanes 4 and 5 with lanes 11 and 12). Since complete medium was added to the cultures prior to apoptosis induction, in part the decrease of radiolabeled La protein might be a result of biological turnover of La phosphorylation. However, the lower dephosphorylation rate in Jurkat/Bcl-2 cells and the previously reported La phosphorylation half-life in K562 cells $(3.6 \mathrm{~h})^{34}$ strongly suggest that La is dephosphorylated as a result of the induction of apoptosis. Western blot analysis using a polyclonal anti-La serum revealed that equal amounts of proteins were analyzed. Interestingly, in addition to the $50 \mathrm{kDa}$ full-length $\mathrm{La}$ band a cleavage product of approximately $45 \mathrm{kDa}$ appeared in anti-Fas treated cells (Figure 1B). This cleavage product was clearly 
A

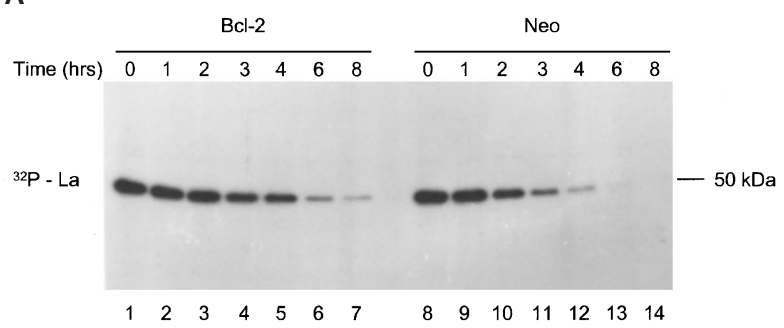

B

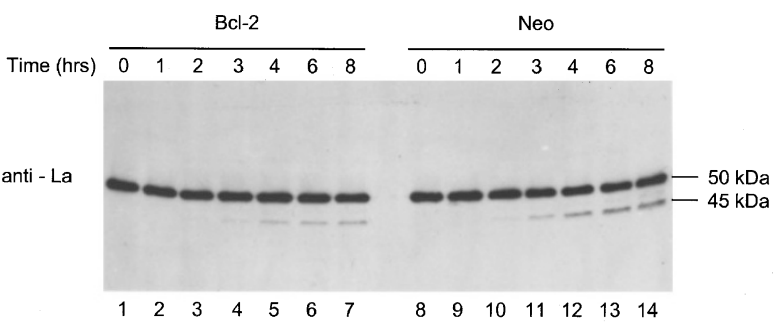

C

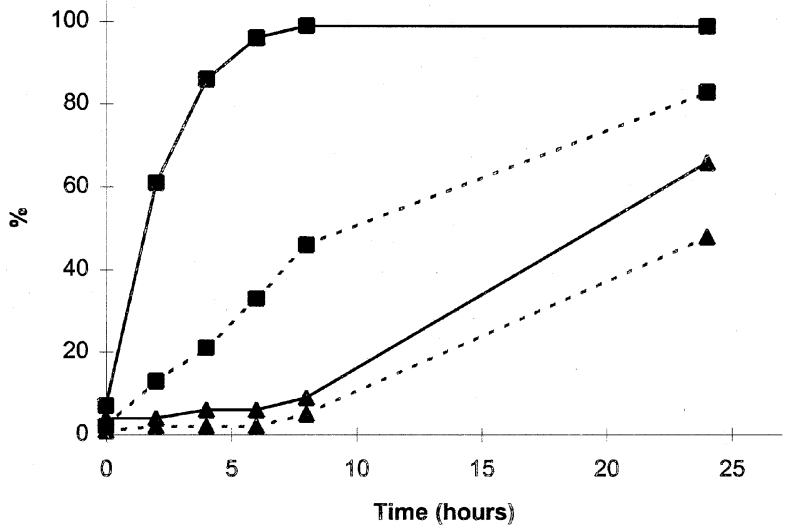

D

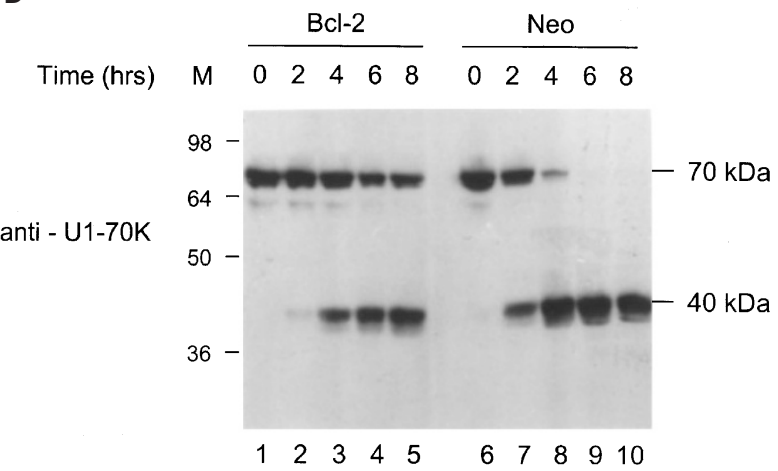

Figure 1 Dephosphorylation and cleavage of the La protein in apoptotic cells. (A,B) ${ }^{32} \mathrm{P}$-labeled Jurkat/Bcl-2 cells (lanes $1-7$ ) and Jurkat/Neo cells (lanes 8 -14) were treated with the anti-Fas monoclonal antibody $7 \mathrm{C} 11$ for the indicated time periods (h). ${ }^{32} \mathrm{P}$-labeled La protein was immunoprecipitated from cell extracts by a monoclonal anti-La antibody (SW5). Following SDSPAGE, proteins were transferred to nitrocellulose and either subjected to autoradiography $(\mathbf{A})$ or Western blot analysis using a polyclonal anti-La serum (B). The positions of the $50 \mathrm{kDa}$ full-length La protein and the $45 \mathrm{kDa}$ cleavage product are indicated on the right. (C) Fas-induced apoptosis in Jurkat cells monitored by flow cytometry. Jurkat/Bcl-2 and Jurkat/Neo cells were stained with annexin V-FITC or propidium iodide (PI) and the percentage of annexin VFITC positive ( $\boldsymbol{\square})$ and PI positive $(\boldsymbol{\Lambda})$ cells was determined using a Coulter Epics Elite flow cytometer. Jurkat/Bcl-2: ( - - ) ), Jurkat/Neo: ( - ). (D) Jurkat/ detectable $3 \mathrm{~h}$ after anti-Fas treatment, and the relative amount of the cleavage product increased with longer incubation times. In some experiments a second apoptotic cleavage product was detected migrating between fulllength $\mathrm{La}$ and the $45 \mathrm{kDa}$ cleavage product (Figure 1B; see also Figure $5 \mathrm{~B}$ ); however, the intensity of this band was always much lower than that of the $45 \mathrm{kDa}$ band.

The efficiency of apoptosis induction was determined by flow cytometry, using Annexin V-FITC and propidium iodide (PI) staining. Four hours after the addition of anti-Fas antibody $80 \%$ of the Jurkat/Neo cells were stained by annexin V-FITC, indicating that these cells express phosphatidylserine, a marker of the early apoptotic state, ${ }^{35}$ at their surface (Figure $1 \mathrm{C}$ ). At this timepoint, only $19 \%$ of the Jurkat cells overexpressing Bcl-2 were annexin V-FITC positive. Staining by PI, indicative of a late apoptotic state of the cells, was hardly observed $8 \mathrm{~h}$ after anti-Fas treatment (only $9 \%$ of Jurkat/Neo and $5 \%$ of Jurkat/Bcl-2 were PI positive). However, when cells were cultured in the presence of anti-Fas antibody for $24 \mathrm{~h}, 66 \%$ of Jurkat/Neo cells and $48 \%$ of the Jukat/Bcl-2 cells were stained by PI. These results demonstrate that induction of apoptosis by anti-Fas treatment is very efficient in our Jurkat cells, whereas the apoptotic process is clearly retarded in the cell line overexpressing Bcl-2.

Additionally, as an internal control for the induction of apoptosis, we analyzed cleavage of the U1-70K protein using a patient serum reactive with $\mathrm{U} 1-70 \mathrm{~K}$, one of the prototypic proteins known to be cleaved during apoptosis. ${ }^{36}$ As shown in Figure 1D, cleavage of the U1-70K protein was observed by the appearance of the $40 \mathrm{kDa}$ cleavage product $2 \mathrm{~h}$ after the addition of 7C11 (Figure 1D, lane 7). By $4 \mathrm{~h}$, the majority of the $\mathrm{U} 1-70 \mathrm{~K}$ protein was cleaved (Figure 1D, lane 8). In contrast, in the Bcl-2 overexpressing cells a significant amount of uncleaved U1-70K protein was still present $8 \mathrm{~h}$ after anti-Fas addition (Figure 1D, lane 5). These results are in good agreement with the efficiency of apoptosis induction as detected by flow cytometry (Figure 1C). In agreement with the inhibitory effect of Bcl-2 on apoptosis as determined by flow cytometry and U1-70K cleavage, we observed inhibition of La cleavage as well. As is demonstrated in Figure $1 \mathrm{~B}$, the $45 \mathrm{kDa}$ fragment cleavage product was hardly detectable $3 \mathrm{~h}$ after anti-Fas addition to the Jurkat/Bcl-2 cells, (Figure 1B, lane 4), although cleavage was clearly observed at later stages.

The results in Figure 1B show that cleavage of the La protein in apoptotic Jurkat cells is incomplete. To further characterize the degree of cleavage, the relative amounts of full-length $\mathrm{La}$ and the apoptotic cleavage product were quantified using a digital chemoluminescence imaging system. In Jurkat/Neo cells, up to $25 \%$ of the La protein was cleaved (at late stages during apoptosis), whereas in

$\mathrm{Bcl}-2(\mathrm{Bcl}-2)$ and Jurkat/Neo (Neo) cells were treated with the anti-Fas monoclonal antibody $7 \mathrm{C} 11$ for the indicated time periods (h). Jurkat/Bcl-2 extracts (lanes $1-5$ ) and Jurkat/Neo extracts (lanes $6-10$ ) were analyzed by SDS-PAGE/Western blotting and immunodetection using a polyclonal antiU1-70K serum. The positions of molecular weight markers are indicated on the left and the designations of the immunostained proteins on the right 
A

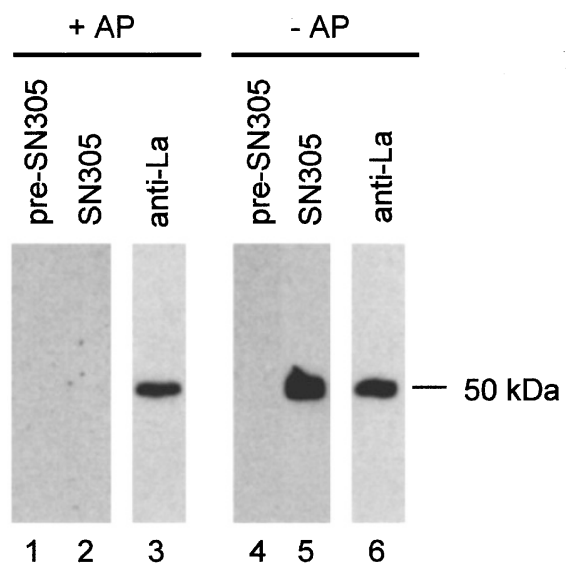

B

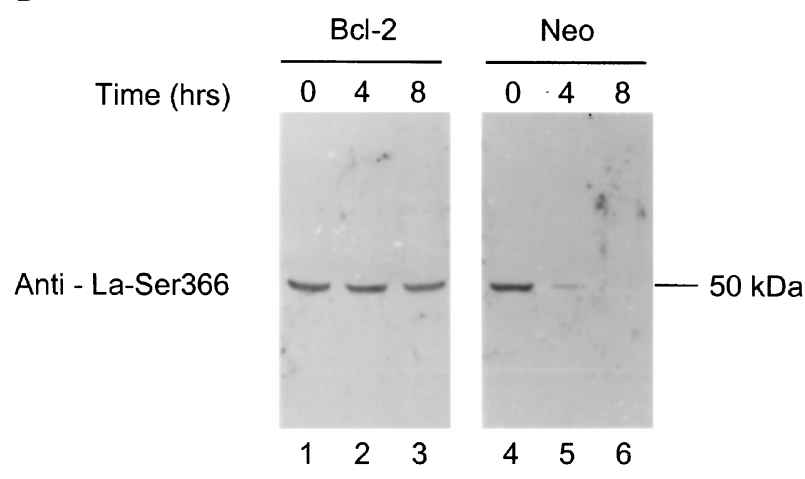

C

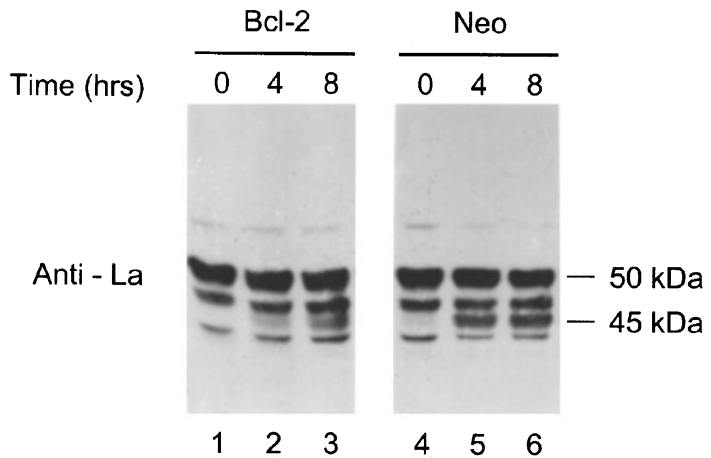

Figure 2 Dephosphorylation of La during apoptosis detected by a rabbit antiserum reactive with a phosphorylated Ser366 epitope of La. (A) Western blot analysis of La, isolated from HeLa S100 extract, with patient anti-La serum (lanes 3 and 6), with rabbit serum SN305, an antiserum raised against a phosphorylated peptide derived from the Ser366 phosphorylation site of La (lanes 2 and 5), and with the corresponding pre-immune serum (lanes 1 and 4). Isolated La protein was either directly analyzed (-AP, lanes 4-6) or was treated with alkaline phosphatase prior to gel electrophoresis (+AP, lanes 1-3). Dephosphorylation of the La protein abrogated the recognition of the protein by SN305 (compare lanes 2 and 5) while the reactivity of the patient serum shows that an equal amount of full-length La protein was present on the blot containing the dephosphorylated material (lanes 3 and 6 ). (B and C) Western blot analysis of apoptotic (anti-Fas induced) Jurkat cell extracts (lanes 1-3: Jurkat/Bcl-2; lanes 4-6: Jurkat/Neo) stained with rabbit serum SN305 (B) or the patient anti-La serum (C). Cell extracts were prepared at the indicated times after apoptosis induction. The positions of the $50 \mathrm{kDa}$ fulllength La protein and the $45 \mathrm{kDa}$ cleavage product are indicated on the right cells overexpressing $\mathrm{Bcl}-2$ a maximum of $7 \%$ La cleavage was measured.

From these results we conclude that the La protein is rapidly dephosphorylated upon induction of apoptosis and that a subset of the La protein molecules is cleaved during apoptosis as well. Both dephosphorylation and cleavage are inhibited by $\mathrm{Bcl}-2$.

To obtain stronger evidence for apoptotically induced dephosphorylation of $\mathrm{La}$, a rabbit antiserum was raised against the phosphorylation site of $\mathrm{La}$ that has been mapped recently to Ser $366^{22}$ by immunization with a synthetic phosphorylated peptide. Western blotting revealed that this serum (SN305) appeared to be highly specific for $\mathrm{La}$ and completely dependent on the phosphorylation state of the protein (Figure 2A). Treatment of the cell extract with alkaline phosphatase prior to blotting abolished recognition of $\mathrm{La}$ by this antiserum, while recognition by a control anti-La antibody was not affected, indicating that the lack of recognition by SN305 was due to the absence of phosphorylated amino acids and not to protein degradation. When the phosphorylation state of $\mathrm{La}$ in apoptotic cells was analyzed with this antiserum (Figure $2 \mathrm{~B}$ ) the results confirmed that $\mathrm{La}$ is specifically dephosphorylated after the induction of apoptosis, while recognition by a control anti-La antibody was not affected (Figure 2C).

\section{A variety of apoptosis inducers leads to La dephosphorylation and cleavage in various cell types}

To determine whether dephosphorylation and cleavage of the La protein are also observed with other apoptotic stimuli, we analyzed apoptotic cell extracts derived from human HeLa cells treated with actinomycin $\mathrm{D}(10 \mu \mathrm{M})$ or HEp-2 cells treated with anisomycin $(10 \mu \mathrm{g} / \mathrm{ml})$ by Western blot analysis using rabbit antiserum SN305 and a polyclonal anti-La patient serum. Consistent with the results for Jurkat cells, both dephosphorylation and cleavage were observed in apoptotic HeLa and HEp-2 cells (data not shown). Furthermore, cleavage of the $\mathrm{La}$ protein was analyzed in cell extracts derived from Jurkat cells treated with anisomycin $(10 \mu \mathrm{g} / \mathrm{ml})$, UV irradiation or the non apoptotic stimulus anti-CD3 by Western blot analysis. Consistent with the results for anti-Fas treated Jurkat cells, cleavage of $\mathrm{La}$ was observed in all cell extracts with the exception of the anti-CD3 treated Jurkat cell extracts (data not shown).

We next analyzed cleavage of the La protein in apoptotic (anisomycin treated) cells derived from mouse 3T3 cells, rat RBL cells and guinea-pig A104 cells and in freshly isolated mouse thymocytes rendered apoptotic by treatment with dexamethasone $(1 \mu \mathrm{M})$ (Figure 3 ). The resulting apoptotic cell extracts were analyzed for the appearance of the La cleavage product by Western blot analysis using an anti-La patient serum. In all cases $\mathrm{La}$ cleavage was observed, although the cleavage product of La in apoptotic mouse, rat and guinea-pig cell extracts migrated more slowly than the major human apoptotic cleavage product. Figure 3 demonstrates the results 
obtained after incubation of freshly isolated mouse thymocytes for $2,4,6$ or $8 \mathrm{~h}$ in the presence of $1 \mu \mathrm{M}$ dexamethasone (compared with mock treated cells as a control). Upon induction of apoptosis by dexamethasone treatment, a La cleavage product appeared within $2 \mathrm{~h}$, and the relative intensity of this band increased over an $8 \mathrm{~h}$ period (Figure 3, lanes 7-10). Induction of apoptosis in all of these cells was monitored by cleavage of either the U1$70 \mathrm{~K}$ protein or the $72 \mathrm{kDa}$ component of the signal recognition particle (data not shown). ${ }^{37}$

\section{Dephosphorylation of La is inhibited by a low concentration of okadaic acid}

Recently it has been demonstrated that protein phosphatase 2A (PP2A) activity is increased 4.5-fold $6 \mathrm{~h}$ after antiFas induced apoptosis in Jurkat cells. ${ }^{38}$ To determine whether this phosphatase activity might be involved in dephosphorylation of the La protein during apoptosis, we pre-incubated Jurkat/Bcl-2 and Jurkat/Neo cells for $1 \mathrm{~h}$ with $50 \mathrm{nM}$ okadaic acid, a concentration which specifically inhibits PP2A activity but does neither inhibit nor induce apoptosis. ${ }^{39}$ Following anti-Fas treatment, the cells were harvested at the indicated timepoints and the phosphorylation state of the La protein in untreated apoptotic cells and apoptotic cells treated with okadaic acid was determined by Western blotting using rabbit serum SN305. As is shown in Figure 4A, dephosphorylation of $L a$ was inhibited in cells treated with okadaic acid (Figure 4A, compare lane 8 with lane 3), suggesting that PP2A is involved in the dephosphorylation of La during apoptosis. Analysis of these cell extracts by an anti-La serum revealed that cleavage of $\mathrm{La}$ was not inhibited by okadaic acid, strongly suggesting that cleavage occurs independently of dephosphorylation (Figure 4B). No differences in U1-70K cleavage were observed between extracts derived from cells treated with $50 \mathrm{nM}$ okadaic acid and untreated cells (data not shown), confirming that this concentration of okadaic acid had no inhibitory effect on apoptosis. Thus, inhibition of $\mathrm{La}$ dephosphorylation is due to inhibition of PP2A rather than inhibition of apoptosis.

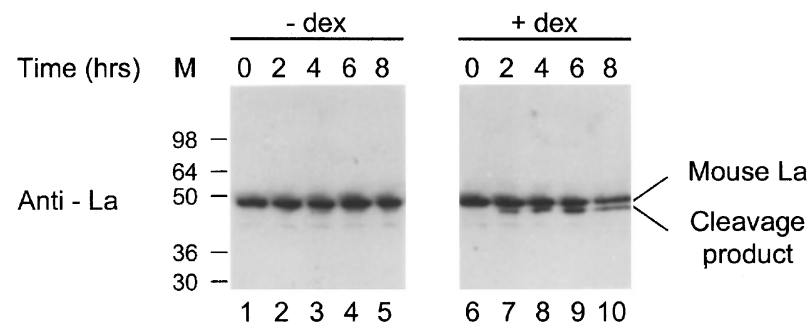

Figure 3 Cleavage of the mouse La protein in apoptotic thymocytes. Freshly isolated mouse thymocytes were cultured in the absence (lanes 1-5) or presence of $1 \mu \mathrm{M}$ dexamethasone (lanes $6-10$ ) to induce apoptosis. After the indicated time periods (in h) cell lysates were analyzed by SDS-PAGE/ Western blotting using a polyclonal anti-La serum. The positions of molecular weight markers and the mouse La protein and its cleavage product are indicated

\section{Effect of caspase inhibitors on dephosphorylation and cleavage of La}

Since the activation of caspases is one of the major universal biochemical features of the execution phase of apoptosis, we investigated whether caspase activation was required for the dephosphorylation and cleavage of La. Therefore, we cultured Jurkat cells in the presence of several caspase inhibitors, including zinc sulphate, the tetrapeptide caspase inhibitors Ac-YVAD-CHO and Ac-DEVD-CHO (aldehyde derivatives) and the irreversible tetrapeptide inhibitors AcYVAD-CMK, Z-DEVD-FMK, Z-IETD-FMK, and Z-LEHD-FMK, for $1 \mathrm{~h}$ prior to induction of apoptosis by addition of anti-Fas antibody. Cells were harvested either immediately, or 4 or $8 \mathrm{~h}$ after addition of anti-Fas. Cell extracts were analyzed by Western blotting using either the phosphorylated La-specific antiserum SN305 or a polyclonal anti-La patient serum. Figure $5 \mathrm{~A}$ demonstrates that dephosphorylation was slightly inhibited in Jurkat cells cultured in the presence of zinc sulphate (Figure 5A, compare lanes 3 and 5). The addition of increasing amounts of Ac-DEVD-CHO resulted in increasing inhibition of La dephosphorylation (Figure 5A, lanes 10-13), while Ac-YVAD-CHO had no detectable effect on dephosphorylation of La (Figure 5A, lanes 6-9). In contrast, increasing amounts of the irreversible caspase inhibitor AcYVAD-CMK resulted in an almost complete inhibition of $\mathrm{La}$ dephosphorylation at a concentration of $20 \mu \mathrm{M}$ (Figure $5 \mathrm{~A}$, lanes 17-20), which is most likely due to the fact that the irreversible inhibitor is a much more potent inhibitor than the aldehyde derivative in cultured cells. Also the other irreversible inhibitors, Z-DEVD-FMK, Z-IETD-FMK and ZLEHD-FMK resulted in inhibition of dephosphorylation (Figure $5 A$, lanes $21-32$ ), albeit with different efficiencies. Note that the data shown in Figure 5 (lanes 1-13 and lanes 14-32) are derived from separate experiments, demonstrating that slight differences between the rate of the apoptotic process in different experiments might occur.

A

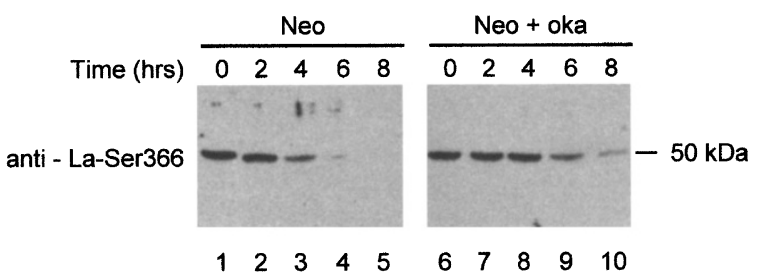

B
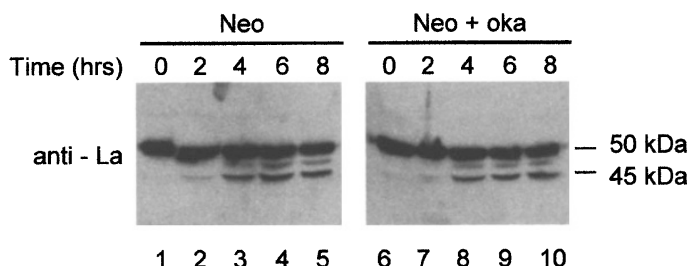

$\begin{array}{lllll}6 & 7 & 8 & 9 & 10\end{array}$

Figure 4 Inhibition of apoptotic La dephosphorylation by okadaic acid. Jurkat/Neo cells were rendered apoptotic by anti-Fas addition either in the absence (lanes 1-5) or in the presence (lanes $6-10$ ) of $50 \mathrm{nM}$ okadaic acid (oka). Cell extracts were prepared at the indicated time points and analyzed by Western blotting using SN305, the antiserum to the phosphorylated Ser366 epitope $(\mathbf{A})$ and by a patient anti-La serum (B) 


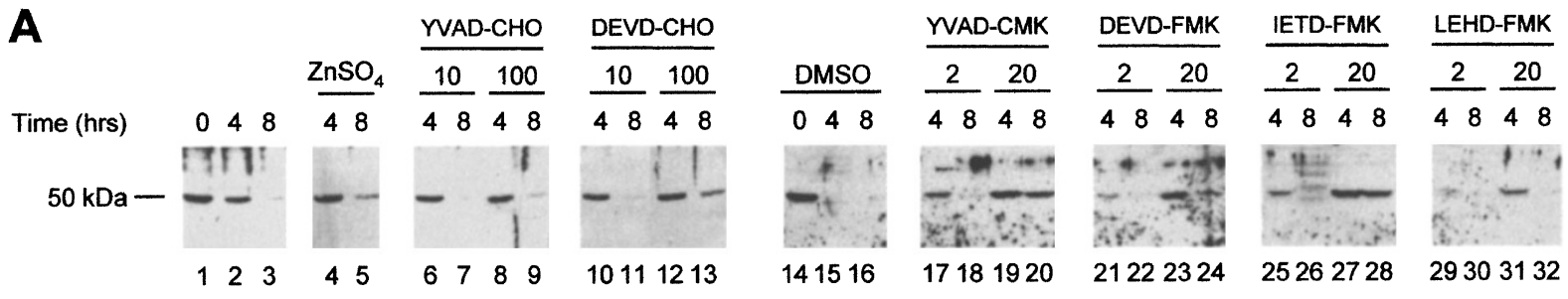

B

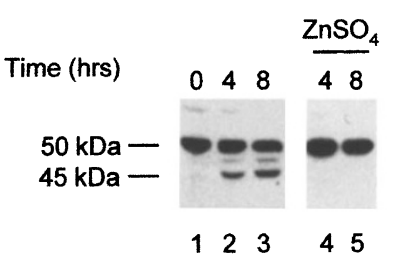

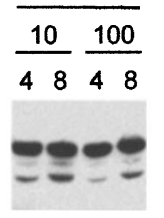

6789

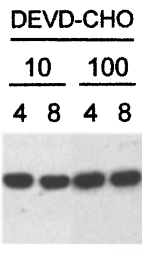

10111213

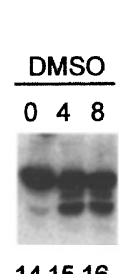

141516

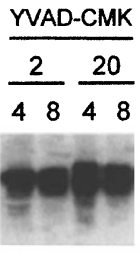

17181920

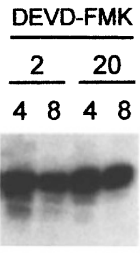

21222324

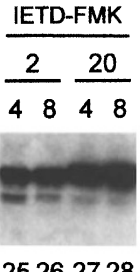

25262728

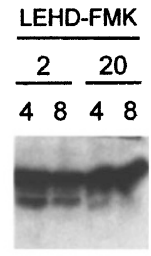

29303132

Figure 5 Effects of apoptosis inhibitors on dephosphorylation and cleavage of La. Jurkat/Neo cells were incubated for $1 \mathrm{~h}$ in the presence of $2 \%$ DMSO (lanes 1 3 and 14-16), $2 \mathrm{mM} \mathrm{ZnSO}_{4}$ (lanes 4 and 5), $10 \mu \mathrm{M}$ (lanes 6-7) and $100 \mu \mathrm{M}$ (lanes 8 and 9) Ac-YVAD-CHO or $10 \mu \mathrm{M}$ (lanes 10 and 11$)$ and 100 $\mu \mathrm{M}$ (lanes 12 and 13) Ac-DEVD-CHO, $2 \mu \mathrm{M}$ (lanes 17 and 18) and $20 \mu \mathrm{M}$ (lanes 19 and 20) Ac-YVAD-CMK, $2 \mu \mathrm{M}$ (lanes 21 and 22) and $20 \mu \mathrm{M}$ (lanes 23 and 24 ) Z-DEVD-FMK, $2 \mu \mathrm{M}$ (lanes 25 and 26) and $20 \mu \mathrm{M}$ (lanes 27 and 28) Z-IETD-FMK or $2 \mu \mathrm{M}$ (lanes 29 and 30) and $20 \mu \mathrm{M}$ (lanes 31 and 32) Z-LEHD-FMK prior to induction of apoptosis with anti-Fas. Cell extracts prepared at the indicated time points were analyzed by SDS-PAGE/immunoblotting using rabbit serum SN305 (A) or a polyclonal anti-La patient serum (B). Note that lanes 1-13 and lanes 14-32 are derived from two separate experiments. The positions of La ( $50 \mathrm{kDa})$ and its major cleavage product $(45 \mathrm{kDa})$ are indicated on the left

Besides dephosphorylation, also apoptotic cleavage of La was affected in the presence of the inhibitors. Figure 5B demonstrates that La cleavage was completely inhibited in Jurkat cells cultured in the presence of zinc sulphate (Figure 5B, lanes 4-5). The addition of AcDEVD-CHO also led to complete inhibition of cleavage (Figure 5B, lanes 10-13), while Ac-YVAD-CHO had no detectable effect on the cleavage of La (Figure 5B, lanes $6-9)$. The irreversible inhibitors all inhibited La cleavage, albeit with different efficiencies (Figure 5B, lanes 14-32). The appearance of the $45 \mathrm{kDa}$ and the $48 \mathrm{kDa}$ cleavage products was equally sensitive to treatment of cells with the caspase inhibitors.

As a control for the inhibitory activity of the tetrapeptide inhibitors, the cell extracts were also analyzed for U1-70K cleavage, which is known to be sensitive to Ac-DEVD$\mathrm{CHO}^{4,36}$ Cleavage of the U1-70K protein was indeed inhibited by $\mathrm{ZnSO}_{4}$ and the tetrapeptide inhibitors with the exception of Ac-YVAD-CHO, although the inhibitor ZLEHD-FMK also in this case inhibited to a lesser extent (data not shown). Similarly, the activity of Ac-YVAD-CHO, which does not inhibit U1-70K cleavage was checked by the analysis of topoisomerase I cleavage, which was indeed inhibited by this reagent (data not shown).

Taken together, these results indicate that both dephosphorylation and cleavage of $\mathrm{La}$ are dependent on the activation of caspases or related proteases. Nevertheless, it should be noted that La cleavage is generally more strongly affected by caspase inhibitors than La dephosphorylation. Since the increase in phosphatase activity of PP2A in apoptotic cells is also dependent on caspase activation, ${ }^{38}$ these results are consistent with PP2A being involved in the dephosphorylation of La. The use of bacterially expressed recombinant caspases-1,-2,-3,-8 and -9 failed to clarify a role for these caspases in the cleavage of the $\mathrm{La}$ protein (data not shown).

\section{Determination of the putative La caspase cleavage site}

Analysis of the amino acid sequence of the human La protein identified three putative caspase cleavage sites (i.e., amino acids $239-242,368-371$ and $371-374$ ). The apparent size of the apoptotic cleavage product suggests that cleavage might occur at Asp371 and/or Asp374. Most interestingly, these amino acids are located very close to Ser366, the major phosphorylation site of La. To investigate this in more detail we compared the electrophoretic mobility of the apoptotic cleavage product with that of several C-terminally truncated mutants of La which were produced by in vitro transcription and translation. A schematic representation of the La protein and the C-terminal deletion mutants of La is shown in Figure $6 \mathrm{~A}$. The in vitro translation products ( $\mathrm{La} \mathrm{wt}, \mathrm{La} \Delta \mathrm{C} 383$, $\mathrm{La} \Delta \mathrm{C} 380, \mathrm{La} \Delta \mathrm{C} 366, \mathrm{La} \Delta \mathrm{C} 355$, La $\Delta \mathrm{C} 344$ ) were resolved in parallel with a non-apoptotic and an apoptotic ( $8 \mathrm{~h}$ after antiFas addition) Jurkat cell extract by SDS-PAGE, and the proteins were detected by Western blotting using an anti-La patient serum. As is shown in Figure 6B, the apoptotic cleavage product (Figure 6B, lane 5) migrated between the deletion mutants La $\Delta$ C380 (Figure 6B, lane 3) and La $\Delta$ C366 (Figure 6B, lane 6). Thus, the electrophoretic behavior of the apoptotic cleavage product of La strongly suggests that $\mathrm{La}$ indeed is cleaved at either Asp371 or Asp374. An alignment of the available La sequences from other organisms that have been analyzed for cleavage of the La protein during apoptosis is shown in Figure 6C. 
A
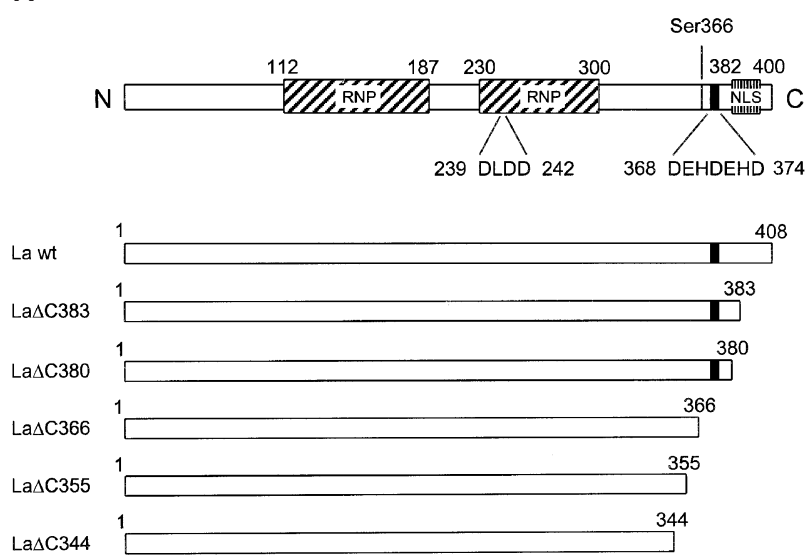

B

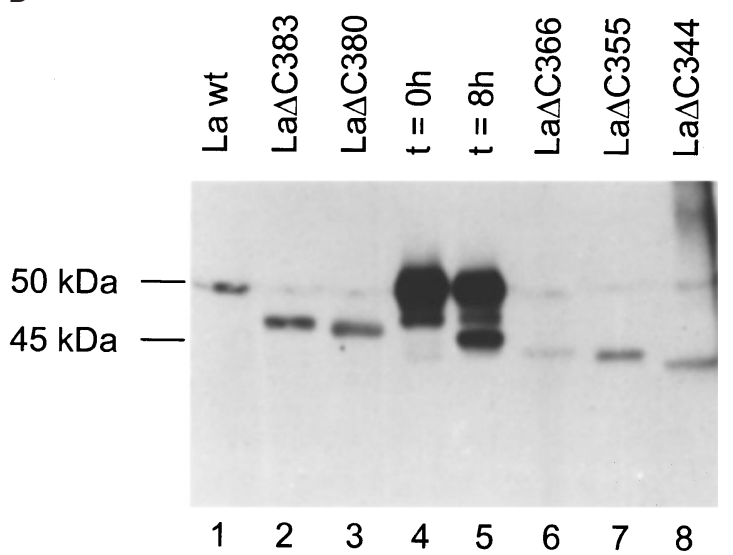

C

Human La 325 LNKWKSKG---1---RRFKGGKGNKAAQPGSGKGKVQFQGKKTKFASDDEHDEHDENGATGPVKRAREETDKEEPASKQQKTENGAGDQ 408 Mouse La 324 LNKWKSKGGHAGGRFKGSHVFTAARRFKGKGKGNRPGYAGAPKGRGQFHGRRTRF---DDDD---1-RRRGPMKRGRDGRDREEPASKHKKRENGARDK 415 Rat La 324 LNKWKSKGGHAARRFKGSHVFTAARRFKGRGKGNRPAYAGAPKGRGQFQGRRTRF---DDDD----HRRGPVKRGIDGRDREEPASKHKKRENGARDK 415

Figure 6 Characterization of the major apoptotic human La cleavage product. (A) A schematic representation of full-length La (La wt) and C-terminal deletion mutants of $\mathrm{La}(\mathrm{La} \Delta \mathrm{C} 383, \mathrm{La} \Delta \mathrm{C} 380$, $\mathrm{La} \Delta \mathrm{C} 366$, $\mathrm{La} \Delta \mathrm{C} 355$ and $\mathrm{La} \Delta \mathrm{C} 344$. The relative positions of the putative caspase recognition motifs (DLDD and DEHDEHD), the phosphorylation site (Ser366), the RNP motifs, and the NLS are indicated. The black box marks the position of the second caspase recognition motif. (B) Fulllength (La wt, lane 1) and C-terminally truncated mutants of La (La $\Delta C 383$, lane 2; La $\Delta C 380$, lane 3; La $\Delta C 366$, lane 6; La $\Delta C 355$, lane 7; La $\Delta C 344$, lane 8) were made by in vitro transcription/translation and electrophoresed in parallel with a non-apoptotic (lane 4) and an apoptotic (lane 5) Jurkat/Neo cell extract. Proteins were detected by immunoblotting using an anti-La patient serum. The positions of full-length La $(50 \mathrm{kDa})$ and its major apoptotic cleavage product $(45 \mathrm{kDa})$ are indicated. (C) Alignment of the C-terminal sequences of human, mouse and rat La proteins. The putative caspase cleavage sites are in bold face, Ser366 of human La is italicized and underlined and the NLS is italicized

\section{Discussion}

Previously, a subcellular relocalization of the La protein has been reported to occur in human keratinocytes during apoptosis initiated by UV irradiation. The La protein appeared to accumulate in nucleus-derived apoptotic bodies. ${ }^{1}$ Here, we have studied molecular changes in the La protein occurring during apoptosis and demonstrate that the La protein is dephosphorylated very efficiently at Ser366. In addition a subset of La molecules is proteolytically cleaved, generating a $45 \mathrm{kDa}$ fragment. These changes appear to be general for the apoptotic process since they were observed after induction of apoptosis by a variety of stimuli and in a variety of cell types. Both dephosphorylation and cleavage were inhibited by co- incubation with zinc (an established apoptosis inhibitor), ${ }^{40}$ as well as with several caspase inhibitors. Dephosphorylation of $\mathrm{La}$ is inhibited by low concentrations of okadaic acid, suggesting that a PP2A-like phosphatase is involved. Based upon the size of the cleavage product and the location of two overlapping putative caspase recognition sequences the cleavage site is most likely located at amino acids 371 or 374 .

What could be the relevance of dephosphorylation and cleavage of La in apoptotic cells? The most well documented function of $\mathrm{La}$ is its activity in RNA synthesis by pol III. The La protein is involved in pol III transcription termination, ${ }^{19,20}$ transcript release ${ }^{20}$ and pol III reinitiation. $^{21,22}$ Accumulating evidence suggests that the cisacting oligo (dT) termination signal functions in RNA 3 '-end 
formation of pol III transcripts, as well as in TFIIIC-mediated assembly and recycling of transcription complexes. ${ }^{41,42}$ This implies that proper termination facilitates efficient transcription. Full-length nascent transcripts are released from their template in a La-dependent fashion with simultaneous release of pol III from the termination complex, which is then available for reinitiation allowing additional rounds of RNA synthesis. ${ }^{21}$ While transcriptional activity of $\mathrm{La}$ is inhibited by phosphorylation of Ser366, ${ }^{23}$ dephosphorylated La, which is active in RNA pol III transcription, inhibits the early post-transcriptional event of $5^{\prime}$-end processing of pre-tRNA. ${ }^{26}$ These data suggest a cycling role for $\mathrm{La}$ in the coordination of transcriptional and early post-transcriptional stages of pol III RNA biogenesis, which is mediated by a phosphorylation/dephosphorylation cycle. During apoptosis this phosphorylation cycle is apparently disrupted, which might have a dramatic effect on pol III RNA biogenesis.

In addition to these nuclear events La has also been implicated in cytoplasmic processes including the (internal) initiation of translation and the modulation of translational activity by inhibiting the activation of the double-stranded RNA-activated protein kinase PKR. ${ }^{43}$ In part these activities may be due to the dsRNA unwinding activity of the La protein. ${ }^{44}$ Both the $\mathrm{N}$ - and $\mathrm{C}$-terminal regions of the protein have been shown to be essential for these activities. ${ }^{45}$ Taken together, a variety of functional activities have been reported for La. Since all of these activities concern processes in which RNA is involved, it is tempting to speculate that La plays a universal role in all of them by acting as an RNA chaperone, a possibility that has recently been suggested by several investigators. ${ }^{24,25}$ Such a general activity would also make the La protein an attractive target for early inactivation during apoptosis, which might result in the simultaneous inhibition of many biosynthetic processes. Of particular interest is the putative apoptotic release of the inhibition of PKR activation due to dephosphorylation and/or cleavage of $\mathrm{La}$, which would result in elevated levels of activated PKR, a protein kinase that may play a central role in early stages of apoptosis. $^{46,47}$

Many proteins have been reported to be cleaved during apoptosis, and this number is still growing. ${ }^{48}$ Cleavage of these proteins in most, if not all cases is a result of the activation of caspases, cysteine proteases with aspartic acid substrate specificity. Many of the caspase targets have important functions such as maintenance of (sub)cellular architecture or repair of damaged cells, and their cleavage is thought to account for the irreversible cellular changes associated with apoptosis. Apoptotic cleavage of La did not proceed to completion in the cells examined (up to $25 \%$ of the molecules were cleaved at late stages of apoptosis). A possible explanation might be the involvement of $\mathrm{La}$ in so many different biosynthetic processes, which might imply that only a subset of the La protein is accessible for caspase activity. Removal of the C-terminal amino acids may have important functional implications for the protein. Previously, we have shown that the nuclear localization signal (NLS) of the La protein resides in the extreme C-terminal end of the molecule (aa
$383-408),{ }^{49}$ implying that cleavage at aa 371 or 374 would remove the complete NLS from the protein. We have observed by immunofluorescence that the (re)distribution of La in apoptotic Jurkat cells is very similar to that seen in apoptotic keratinocytes. ${ }^{1}$ Also in Jurkat cells La appeared to accumulate in apoptotic bodies during apoptosis (our unpublished observations). Due to the lack of an antibody specifically recognizing the apoptotic La cleavage product, the relatively low level of cleavage product at early stages of apoptosis and the characteristic morphological changes occurring in apoptotic cells, no conclusions could be drawn on the effect of the removal of the NLS on the subcellular distribution of La.

The significance of La cleavage for the progression of the apoptotic process is unknown. However, the relatively late onset of La cleavage during the apoptotic process and the fact that the majority of La molecules is not cleaved argue against a significant role. It is clear that, if cleavage of the La protein is a key event in the execution phase of apoptosis, this only holds true for a subset of the La molecules. Given the variety of processes in which La has been proposed to play a role, it would be interesting to investigate which features determine whether a La molecule is cleaved or not cleaved. Interestingly, Ser366 is located very close to the putative caspase cleavage sites, raising the intriguing possibility that dephosphorylation of $\mathrm{La}$ at Ser366 is required for cleavage to occur. However, since okadaic acid inhibited dephosphorylation of La but did not affect cleavage of the La protein, cleavage and dephosphorylation appear to be two independent processes. This implies that in principle also the $45 \mathrm{kDa}$ cleavage product might be phosphorylated. The fact that no phosphorylated cleavage product was detected in apoptotic cells is most likely due to both the rate and the degree of dephosphorylation, both being much higher than for cleavage. Although in the presence of okadaic acid the conditions might have been more favorable to detect a phosphorylated cleavage product, no such protein was detected. This might be explained by either the only partial inhibition of dephosphorylation (the experimental setup did not allow the usage of higher concentrations of phosphatase inhibitor) or by the possibility that the epitope(s) recognized by rabbit serum SN305 was disrupted by the cleavage. Attempts to develop an in vitro apoptotic cleavage assay for La have been unsuccessful, which complicates a more precise determination of the cleavage site and identification of the caspase(s) involved.

An alignment of the available La sequences of those organisms that have been analyzed for cleavage of the La protein during apoptosis is shown in Figure 6C. In the Cterminal region of both mouse and rat La two putative caspase cleavage sites are present, one at position 377380 (DDDD) and one at position 391-394 (DGRD). If the latter site is the actual caspase cleavage site, which is expected to be a much better caspase substrate than the former, ${ }^{50}$ this might explain the difference in electrophoretic mobility observed between the $45 \mathrm{kDa}$ cleavage products of human $\mathrm{La}$ on the one hand and the approximately $48 \mathrm{kDa}$ cleavage product of mouse (Figure 3 ), rat and guinea-pig $\mathrm{La}$ on the other. In addition, the 
minor cleavage product of human La (approximately $48 \mathrm{kDa}$ ) migrating between the $45 \mathrm{kDa}$ cleavage product and the full-length human La protein may correspond to the cleavage product of mouse, rat and guinea-pig La, since another putative caspase cleavage site (387-EETD390 ) is present at an equivalent position in the human sequence (Figure $6 \mathrm{C}$ ). ${ }^{50}$ Surprisingly, in both the mouse and rat La proteins Ser366 homologs are lacking. Nevertheless, Ser366 phosphorylation in the human La protein, which resides in a CKII consensus sequence ((S/ $\mathrm{T}) \mathrm{XX}(\mathrm{D} / \mathrm{E})),{ }^{51}$ has been unequivocally demonstrated and phosphorylation of this residue appeared to regulate the transcription factor activity and to affect pre-tRNA processing. $^{23,25,27}$ In both mouse and rat La a threonine is present at amino acid 386 flanked by the amino acids RFD, which thus might represent a CKII phosphorylation site located at an almost equivalent position. Since the Ctermini of La proteins from several species (Ser366 conservation is observed in bovine, rabbit and Xenopus laevis La) contain CKII consensus sites, the physiological significance of this phosphorylation site is likely to be conserved as well.

Dephosphorylation of several proteins is known to occur during apoptosis, including the retinoblastoma protein, a protein involved in cell cycle progression, ${ }^{52-55}$ FAST kinase, which phosphorylates the TIA-1 RNA binding protein upon its dephosphorylation ${ }^{56}$ and the family of ERM (Ezrin/Radixin/Moesin) proteins, which play a role in microvillar formation. Apoptotic dephosphorylation of autoantigens has not yet been reported, although several hyperphosphorylated SR proteins appear to stably associate with the U1 snRNP during cell death. ${ }^{10,58}$ La represents the first autoantigen that is rapidly dephosphorylated during cell death. Two candidate phosphatases that are activated during apoptosis have been recently described, including mitogen-activated protein kinase phosphatase- $1^{59}$ and protein phosphatase $2 \mathrm{~A} .^{38,} 60$ Interestingly, PP2A was identified in a yeast 2 hybrid screen using caspase- 3 as bait. Upon induction of apoptosis in Jurkat cells, the regulatory subunit of PP2A is cleaved by caspase-3, thereby increasing PP2A activity 4.5 -fold $6 \mathrm{~h}$ after antiFas treatment. The effects on PP2A could be prevented by the caspase inhibitors Ac-DEVD-CHO and Ac-DEVD-FMK. Inhibition of La dephosphorylation by low concentrations of okadaic acid and by the caspase inhibitor Ac-DEVD-CHO support the hypothesis that PP2A or a related phosphatase is involved.

It has been proposed that post-translational modifications, such as proteolysis, phosphorylation, modification by transglutaminase, ubiquitination and poly(ADP-ribosyl)ation may produce novel epitopes or enhance the exposure of the (modified) antigens to the immune system (reviewed by Utz and Anderson ${ }^{8}$ ). However, only a subset of the known autoantigens is cleaved during apoptosis and even fewer autoantigens are known to undergo other types of modifications. In view of the present findings for $\mathrm{La}$ it can be anticipated that unique apoptotic modifications will be found for other autoantigens in the near future. Additional studies are required to investigate whether dephosphorylation and cleavage of the La protein during apoptosis might play a crucial role in the breaking of immunological tolerance to this protein.

\section{Materials and Methods}

\section{Cell culture}

Jurkat cells, with Bcl-2 (Jurkat/Bcl-2) or without Bcl-2 (Jurkat/Neo) overexpression, were grown in RPMI (Gibco BRL) medium supplemented with $10 \%$ heat-inactivated fetal calf serum, $200 \mu \mathrm{g} / \mathrm{ml}$ G418 (Gibco BRL), $1 \mu \mathrm{M} \beta$-mercapthoethanol, $1 \mathrm{mM}$ sodium-pyruvate and penicillin and streptomycin. Freshly isolated mouse thymocytes were grown in RPMI medium supplemented with $10 \%$ heat-inactivated fetal calf serum, $1 \mathrm{mM}$ sodium-pyruvate and penicillin and streptomycin. HeLa cells, HEp-2 cells, Rat basophilic leukemia cells (RBL), mouse 3T3 cells and guinea-pig A104 cells were grown in DMEM supplemented with $10 \%$ heat-inactivated fetal calf serum and penicillin and streptomycin. Cells were cultured in $5 \% \mathrm{CO}_{2}$ at $37^{\circ} \mathrm{C}$.

\section{Preparation of apoptotic cell extracts}

Jurkat cells were treated with an anti-Fas monoclonal antibody $7 \mathrm{C} 11$, a kind gift of Dr. M Robertson (Indiana University, Bloomington, IN, USA), $10 \mu \mathrm{g} / \mathrm{ml}$ anisomycin, anti-CD3, or UV irradiation as described $^{37}$ and cells were incubated at $37^{\circ} \mathrm{C}$ for the indicated time periods prior to harvesting. HeLa cells were treated with $10 \mu \mathrm{M}$ actinomycin D, HEp-2 cells, RBL cells, 3T3 cells and A104 cells were treated with $10 \mu \mathrm{g} / \mathrm{ml}$ anisomycin, freshly isolated mouse thymocytes were treated with $1 \mu \mathrm{M}$ dexamethasone. Cells were lysed in NP-40 lysis buffer (25 mM Tris, pH 7.5, $100 \mathrm{mM} \mathrm{KCl,} 0.25 \mathrm{mM}$ DTE $10 \mathrm{mM}$ $\mathrm{MgCl}_{2}, 1 \%$ NP-40, protease inhibitor cocktail from Boehringer Mannheim) for $30 \mathrm{~min}$ on ice. After centrifugation for $15 \mathrm{~min}$ at $12000 \times g$, supernatants were analyzed by Western blotting. Monolayer cells were trypsinized, washed with PBS and lysed as above. For experiments utilizing the phosphatase inhibitor and caspase inhibitors, Jurkat cells were cultured in the presence of either $50 \mathrm{nM}$ okadaic acid, $2 \%$ DMSO, $2 \mathrm{mM} \mathrm{ZnSO}_{4}, 10$ or $100 \mu \mathrm{M} \mathrm{Ac-}$ YVAD-CHO (Calbiochem), 10 or $100 \mu \mathrm{M}$ Ac-DEVD-CHO (Calbiochem), 2 or $20 \mu \mathrm{M}$ Ac-YVAD-CMK (Calbiochem), 2 or $20 \mu \mathrm{M}$ Z-DEVDFMK (Calbiochem), 2 or $20 \mu \mathrm{M}$ Z-IETD-FMK (Calbiochem) or 2 or $20 \mu \mathrm{M}$ Z-LEHD-FMK (Calbiochem). Subsequently, apoptosis was induced by the addition of anti-Fas monoclonal antibody followed by harvesting after incubation as indicated and lysis as described above.

\section{Flow cytometry}

To monitor the induction of apoptosis in Jurkat cells by anti-Fas treatment, cells were stained with annexin $\mathrm{V}$ conjugated to fluorescein isothiocyanate (FITC) $(1 \mu \mathrm{g} / \mathrm{ml})$ in RPMl $/ 10 \%$ fetal calf serum $/ 2.5 \mathrm{mM}$ $\mathrm{CaCl}_{2}$ for $2 \mathrm{~min}$ at room temperature followed by propidium iodide $(5 \mu \mathrm{g} / \mathrm{ml})$ staining for $10 \mathrm{~min}$ at $4^{\circ} \mathrm{C}$. Cell staining was determined using a Coulter Epics Elite flow cytometer.

\section{Western blot analysis}

Cell extracts were fractionated by SDS-PAGE (10\%) and blotted onto a nitrocellulose filter. After blocking the filters in wash buffer $(5 \%$ skimmed milk, PBS, $0.1 \%$ NP-40) for $1 \mathrm{~h}$ at room temperature, filters were incubated with patient serum C25 (anti-La), H42 (anti-U1-70K), Z28 (anti-topoisomerase I) (1/5000) or rabbit serum (SN305) (1/2500) in wash buffer for $1 \mathrm{~h}$ at room temperature. After washing three times for $15 \mathrm{~min}$, binding of antibodies was visualized by incubation with peroxidase-conjugated rabbit anti-human antibodies or swine anti- 
rabbit antibodies (Dako) followed by chemoluminescence detection. Rabbit antisera reactive with phosphorylated serine-366 of the human La protein were raised against a peptide corresponding to aa 361371 of the human La protein $\left(\mathrm{H}_{2} \mathrm{~N}-\mathrm{CKTKFASDDEHD-CONH}{ }_{2}\right)$ carrying a phosphorylated serine (Eurogentec, Seraing, Belgium).

\section{Metabolic labeling and immunoprecipitation}

Jurkat/Bcl-2 and Jurkat/Neo cells were incubated at a density of $2 \times 10^{6} \mathrm{cell} / \mathrm{s} / \mathrm{ml}$ in labeling medium (RPMl without phosphate (ICN), $2 \mathrm{mM}$ glutamax (Gibco-BRL), 5\% dialyzed fetal calf serum $1 \mathrm{mM}$ sodium-pyruvate, $10 \mathrm{mM}$ HEPES $(\mathrm{pH} \mathrm{7.4)}$ ) and penicillin and streptomycin). ${ }^{32} \mathrm{P}$-labeled orthophosphate was added at a concentration of $33 \mu \mathrm{Ci} / \mathrm{ml}$. After incubating the cells at $37^{\circ} \mathrm{C}$ for $18 \mathrm{~h}$, an equal volume of RPMI (Gibco BRL) medium supplemented with $10 \%$ heatinactivated fetal calf serum, $200 \mu \mathrm{g} / \mathrm{ml}$ G418 (Gibco BRL), $1 \mu \mathrm{M} \beta$ mercapthoethanol, $1 \mathrm{mM}$ sodium-pyruvate, $10 \mathrm{mM}$ HEPES ( $\mathrm{pH} 7.4)$ and penicillin and streptomycin was added. Cells were treated with an anti-Fas monoclonal antibody $7 \mathrm{C} 11$ and incubated at $37^{\circ} \mathrm{C}$. Radiolabeled cells were either solubilized in NP-40 lysis buffer immediately or after incubation for 1, 2, 3, 4, 6 or $8 \mathrm{~h}$. Cell lysates were incubated on ice for $30 \mathrm{~min}$, followed by centrifugation for $15 \mathrm{~min}$ at $4^{\circ} \mathrm{C}$ at $12000 \times \mathrm{g}$. To immunoprecipitate radiolabeled La protein, protein A-agarose beads were incubated with an anti-La monoclonal antibody (SW5) by rotation for at least $1 \mathrm{~h}$ in $\mathrm{IPP}_{500}(10 \mathrm{mM}$ Tris- $\mathrm{HCl}$ (pH 7.5), $500 \mathrm{mM} \mathrm{NaCl}, 0.05 \% \mathrm{NP}-40$ ) followed by washing twice with IPP $_{500}$ and twice with TKED (10 mM Tris- $\mathrm{HCl}(\mathrm{pH} 8.0), 100 \mathrm{mM} \mathrm{KCl}$, $1 \mathrm{mM}$ DTE, $1 \mathrm{mM}$ EDTA, $0.05 \% \mathrm{NP}-40$ ). After rotating the coated beads with the radiolabeled extracts in TKED for $2 \mathrm{~h}$ at $4^{\circ} \mathrm{C}$, the beads were washed three times with TKED and radiolabeled proteins were analyzed by $10 \%$ SDS-polyacrylamide gel electrophoresis and subjected either to autoradiography or Western blotting.

\section{In vitro transcription and translation}

In vitro transcription and translation were performed as described. ${ }^{49,61}$ Wild-type $\mathrm{La}$ and $\mathrm{La} \Delta \mathrm{C} 380$ protein were produced after linearization with Hindll and Avall, respectively. Mutants La $\Delta$ C383 and La $\Delta$ C355 were made by linearizing La383/4 and La355/6 with BamHI, La $\Delta$ C366 was made by linearizing La366/7 with Narl and La $\Delta$ C344 was made by linearizing La344/6 with Clal. ${ }^{49}$

\section{Acknowledgements}

We thank Dr. M Robertson for kindly providing the anti-Fas monoclonal antibody 7C11; J Reed for the gift of the Bcl-2- and Neo-overexpressing Jurkat cells and Mieke van Bruggen for assistance with the isolation of mouse thymocytes and with flow cytometry. This work was supported in part by the Netherlands Foundation for Chemical Research (SON) with financial aid from the Netherlands Organization for Scientific Research (NWO). The work of PJ Utz was supported by the Arthritis Foundation, the Scleroderma Foundation, Inc., National Institutes of Health Grants K08AI01521 and AR42689, the Harvard Skin Disease Research Center.

\section{References}

1. Casciola Rosen LA, Anhalt G and Rosen A (1994) Autoantigens targeted in systemic lupus erythematosus are clustered in two populations of surface structures on apoptotic keratinocytes. J. Exp. Med. 179: 1317-1330

2. Casiano CA, Martin SJ, Green DR and Tan EM (1996) Selective cleavage of nuclear autoantigens during CD95 (Fas/APO-1)-mediated T cell apoptosis. J. Exp. Med. 184: $765-770$
3. Alnemri ES, Livingston DJ, Nicholson DW, Salvesen G, Thornberry NA, Wong WW and Yuan J (1996) Human ICE/CED-3 protease nomenclature. Cell 87: 171

4. Casciola Rosen LA, Miller DK, Anhalt GJ and Rosen A (1994) Specific cleavage of the 70-kDa protein component of the U1 small nuclear ribonucleoprotein is a characteristic biochemical feature of apoptotic cell death. J. Biol. Chem. 269: $30757-30760$

5. Lazebnik YA, Kaufmann SH, Desnoyers S, Poirier GG and Earnshaw WC (1994) Cleavage of poly(ADP-ribose) polymerase by a proteinase with properties like ICE. Nature 371: $346-347$

6. Waterhouse N, Kumar S, Song QH, Strike P, Sparrow L, Dreyfuss G, Alnemri ES, Litwack G, Lavin M and Watters D (1996) Heteronuclear ribonucleoproteins C1 and $\mathrm{C} 2$, components of the spliceosome, are specific targets of interleukin 1 betaconverting enzyme-like proteases in apoptosis. J. Biol. Chem. 271: 2933529341

7. Cryns VL, Bergeron L, Zhu H, Li H and Yuan J (1996) Specific cleavage of alphafodrin during Fas-and tumornecrosis factor-induced apoptosis is mediated by an interleukin-1beta-converting enzyme/Ced-3 protease distinct from the poly(ADP-ribose) polymerase protease. J. Biol. Chem. 271: 31277-31282

8. Utz PJ and Anderson P (1998) Posttranslational protein modifications, apoptosis, and the bypass of tolerance to autoantigens. Arthritis Rheum. 41 : $1152-1160$

9. Casciola Rosen L, Wigley F and Rosen A (1997) Scleroderma autoantigens are uniquely fragmented by metal-catalyzed oxidation reactions: implications for pathogenesis. J. Exp. Med. 185: 71-79

10. Utz PJ, Hottelet M, Van Venrooij WJ and Anderson P (1998) Association of phosphorylated serine/arginine (SR) splicing factors with the U1-small ribonucleoprotein (snRNP) autoantigen complex accompanies apoptotic cell death. J. Exp. Med. 187: 547-560

11. Stetler DA and Jacob ST (1984) Phosphorylation of RNA polymerase laugments its interaction with autoantibodies of systemic lupus erythematosus patients. J. Biol. Chem. 259: 13629-13632

12. Satoh M, Ajmani AK, Ogasawara T, Langdon JJ, Hirakata M, Wang Jand Reeves WH (1994) Autoantibodies to RNA polymerase II are common in systemic lupus erythematosus and overlap syndrome. Specific recognition of the phosphorylated (IIO) form by a subset of human sera. J. Clin. Invest. 94: 1981-1989

13. Autuori F, Farrace MG, Oliverio S, Piredda L and Piacentini M (1998) 'Tissue' transglutaminase and apoptosis. Adv. Biochem. Eng. Biotechnol. 62: 129-136

14. Marushige $Y$ and Marushige $K$ (1995) Disappearance of ubiquitinated histone H2A during chromatin condensation in TGF beta 1-induced apoptosis. Anticancer Res. 15: 267-272

15. Elouaai F, Lule J, Benoist H, Appolinaire Pilipenko S, Atanassov C, Muller S and Fournie GJ (1994) Autoimmunity to histones, ubiquitin, and ubiquitinated histone $\mathrm{H} 2 \mathrm{~A}$ in NZB $x$ NZW and MRL-Ipr/lpr mice. Anti-histone antibodies are concentrated in glomerular eluates of lupus mice. Nephrol. Dial. Transplant 9: $362-366$

16. Yoon YS, Kim JW, Kang KW, Kim YS, Choi KH and Joe CO (1996) Poly(ADPribosyl)ation of histone $\mathrm{H} 1$ correlates with internucleosomal DNA fragmentation during apoptosis. J. Biol. Chem. 271: 9129-9134

17. Simbulan-Rosenthal CM, Rosenthal DS, lyer S, Boulares AH and Smulson ME (1998) Transient poly(ADP-ribosyl)ation of nuclear proteins and role of poly(ADP-ribose) polymerase in the early stages of apoptosis. J. Biol. Chem. 273: $13703-13712$

18. Rinke J and Steitz JA (1982) Precursor molecules of both human 5 S ribosomal RNA and transfer RNAs are bound by a cellular protein reactive with anti-La lupus antibodies. Cell 29: 149-159

19. Gottlieb E and Steitz JA (1989) The RNA binding protein La influences both the accuracy and the efficiency of RNA polymerase III transcription in vitro. EMBO J. 8: $841-850$

20. Gottlieb E and Steitz JA (1989) Function of the mammalian La protein: evidence for its action in transcription termination by RNA polymerase III. EMBO J. 8:851 861

21. Maraia RJ, Kenan DJ and Keene JD (1994) Eukaryotic transcription termination factor La mediates transcript release and facilitates reinitiation by RNA polymerase III. Mol. Cell. Biol. 14: 2147-2158

22. Maraia RJ (1996) Transcription termination factor La is also an initiation factor for RNA polymerase III. Proc. Natl. Acad. Sci. USA 93: 3383-3387

23. Fan H, Sakulich AL, Goodier JL, Zhang XL, Qin J and Maraia RJ (1997) Phosphorylation of the human La antigen on serine 366 can regulate recycling of RNA polymerase III transcription complexes. Cell 88: 707-715. 
24. Lin Marq N and Clarkson SG (1998) Efficient synthesis, termination and release of RNA polymerase III transcripts in Xenopus extracts depleted of La protein. EMBO J. 17: 2033-2041

25. Yoo CJ and Wolin SL (1997) The yeast La protein is required for the 3 endonucleolytic cleavage that matures tRNA precursors. Cell 89: 393-402

26. Fan H, Goodier JL, Chamberlain JR, Engelke DR and Maraia RJ (1998) 5 processing of tRNA precursors can be modulated by the human La antigen phosphoprotein. Mol. Cell. Biol. 18: 26980-25964

27. Vanhorn DJ, Yoo CJ, Xue DH, Shi H and Wolin SL (1997) The La protein in Schizosaccharomyces pombe: A conserved yet dispensable phosphoprotein that functions in tRNA maturation. RNA 3: 1434-1443

28. Meerovitch K, Svitkin YV, Lee HS, Lejbkowicz F, Kenan DJ, Chan EKL, Agol VI, Keene JD and Sonenberg N (1993) La autoantigen enhances and corrects aberrant translation of poliovirus RNA in reticulocyte lysate. J. Virol. 67: 3798 3807

29. Svitkin YV, Meerovitch K, Lee HS, Dholakia JN, Kenan DJ, Agol VI and Sonenberg N (1994) Internal translation initiation on poliovirus RNA: further characterization of La function in poliovirus translation in vitro. J. Virol. 68: 1544 1550

30. Park YW and Katze MG (1995) Translational control by influenza virus. J. Biol. Chem. 270: 28433-28439

31. Pellizzoni L, Cardinali B, Linmarq N, Mercanti D and Pierandrei-Amaldi P (1996) A Xenopus laevis homologue of the La autoantigen binds the pyrimidine tract of the $5^{\prime}$ UTR of ribosomal protein mRNAs in vitro: Implication of a protein factor in complex formation. J. Mol. Biol. 259: $904-915$

32. Pogue GP, Hofmann J, Duncan R, Best JM, Etherington J, Sontheimer RD and Nakhasi HL (1996) Autoantigens interact with cis-acting elements of rubella virus RNA. J. Virol. 70: 6269-6277

33. Casciola Rosen LA, Anhalt GJ and Rosen A (1995) DNA-dependent protein kinase is one of a subset of autoantigens specifically cleaved early during apoptosis. J. Exp. Med. 182: 1625-1634

34. Pfeifle J, Anderer FA and Franke M (1987) Multiple phosphorylation of human SS-B/LA autoantigen and its effect on poly(U) and autoantibody binding. Biochim. Biophys. Acta 928: 217-226

35. Fadok VA, Voelker DR, Campbell PA, Cohen JJ, Bratton DL and Henson PM (1992) Exposure of phosphatidylserine on the surface of apoptotic lymphocytes triggers specific recognition and removal by macrophages. J. Immunol. 148 2207-2216

36. Casciola Rosen L, Nicholson DW, Chong T, Rowan KR, Thornberry NA, Miller DK and Rosen A (1996) Apopain/CPP32 cleaves proteins that are essential for cellular repair: a fundamental principle of apoptotic death. J. Exp. Med. 183 1957- 1964

37. Utz PJ, Hottelet M, Van Venrooij WJ and Anderson P (1998) The 72 kDa component of signal recognition particle (SRP) is cleaved during apoptosis. $J$. Biol. Chem. 273: 35362-35370

38. Santoro MF, Annand RR, Robertson MM, Peng YW, Brady MJ, Mankovich JA Hackett MC, Ghayur T, Walter G, Wong WW and Giegel DA (1998) Regulation of protein phosphatase $2 \mathrm{~A}$ activity by caspase-3 during apoptosis. J. Biol. Chem. 273: $13119-13128$

39. Morana SJ, Wolf CM, Li J, Reynolds JE, Brown MK and Eastman A (1996) The involvement of protein phosphatases in the activation of ICE/CED-3 protease, intracellular acidification, DNA digestion, and apoptosis. J. Biol. Chem. 271 18263-18271

40. Takahashi A, Alnemri ES, Lazebnik YA, Fernandes Alnemri T, Litwack G, Moir RD, Goldman RD, Poirier GG, Kaufmann SHand EarnshawWC (1996) Cleavage of lamin A by Mch2 alpha but not CPP32: multiple interleukin 1 beta-converting enzyme-related proteases with distinct substrate recognition properties are active in apoptosis. Proc. Natl. Acad. Sci. USA 93: 8395-8400

41. Dieci G and Sentenac A (1996) Facilitated recycling pathway for RNA polymerase III. Cell 84: 245-252

42. Wang $Z$ and Roeder RG (1996) TFIIIC1 acts through a downstream region to stabilize TFIIIC2 binding to RNA polymerase III promoters. Mol. Cell. Biol. 16: $6841-6850$
43. Xiao Q, Sharp TV, Jeffrey IW, James MC, Pruijn GJ, Van Venrooij WJ and Clemens MJ (1994) The La antigen inhibits the activation of the interferoninducible protein kinase PKR by sequestering and unwinding double-stranded RNA. Nucleic Acids Res. 22: 2512-2518

44. Huhn P, Pruijn GJM, Van Venrooij WJ and Bachmann M (1997) Characterization of the autoantigen La (SSB) as a dsRNA unwinding enzyme. Nucleic Acids Res. 25: $410-416$

45. Craig AWB, Svitkin YV, Lee HS, Belsham GJ and Sonenberg N (1997) The La autoantigen contains a dimerization domain that is essential for enhancing translation. Mol. Cell. Biol. 17: 163-169.

46. Yeung MC, Liu J and Lau AS (1996) An essential role for the interferon-inducible, double-stranded RNA-activated protein kinase PKR in the tumornecrosis factorinduced apoptosis in U937 cells. Proc. Natl. Acad. Sci. USA 93: 12451-12455

47. Srivastava SP, KumarKU and Kaufman RJ (1998) Phosphorylation of eukaryotic translation initiation factor 2 mediates apoptosis in response to activation of the double-stranded RNA-dependent protein kinase. J. Biol. Chem. 273: 24162423

48. Porter AG, Ng P and Janicke RU (1997) Death substrates came alive. Bioessays 19: $501-507$

49. Simons FHM, Broers FJM, Van Venrooij WJ and Pruijn GJM (1996) Characterization of cis-acting signals for nuclear import and retention of the $\mathrm{La}$ (SS-B) autoantigen. Exp. Cell Res. 224: 224-236.

50. Thornberry NA, Rano TA, Peterson EP, Rasper DM, Timkey T, Garcia Calvo M, Houtzager VM, Nordstrom PA, Roy S, Vaillancourt JP, Chapman KT and Nicholson DW (1997) A combinatorial approach defines specificities of members of the caspase family and granzyme B. Functional relationships established for key mediators of apoptosis. J. Biol. Chem. 272: 17907-17911

51. Bairoch A, Bucher P and Hofmann K (1996) The PROSITE database, its status in 1995. Nucleic Acids Res. 24: $189-196$

52. Dou QP, An B and Will PL (1995) Induction of a retinoblastoma phosphatase activity by anticancer drugs accompanies p53-independent G1 arrest and apoptosis. Proc. Natl. Acad. Sci. USA 92: 9019-9023

53. Dou QP, An B, Antoku K and Johnson DE (1997) Fas stimulation induces RB dephosphorylation and proteolysis that is blocked by inhibitors of the ICE protease family. J. Cell. Biochem. 64: 586-594

54. Wolf CM, Reynolds JE, Morana SJ and Eastman A (1997) The temporal relationship between protein phosphatase, ICE/CED-3 proteases, intracellular acidification, and DNA fragmentation in apoptosis. Exp. Cell Res. 230: 22-27

55. Fattman CL, An B and Dou QP (1997) Characterization of interior cleavage of retinoblastoma protein in apoptosis. J. Cell. Biochem. 67: 399-408

56. Tian Q, Taupin J, Elledge S, Robertson M and Anderson P (1995) Fas-activated serine/threonine kinase (FAST) phosphorylates TIA-1 during Fas-mediated apoptosis. J. Exp. Med. 182: 865-874

57. Kondo T, Takeuchi K, Doi Y, Yonemura S, Nagata S and Tsukita S (1997) ERM (ezrin/radixin/moesin)-based molecular mechanism of microvillar breakdown at an early stage of apoptosis. J. Cell Biol. 139: 749-758

58. Utz PJ, Hottelet M, Schur PH and Anderson P (1997) Proteins phosphorylated during stress-induced apoptosis are common targets for autoantibody production in patients with systemic lupus erythematosus. J. Exp. Med. 185: $843-854$

59. Franklin CC, Srikanth S and Kraft AS (1998) Conditional expression of mitogenactivated protein kinase phosphatase-1, MKP-1, is cytoprotective against UVinduced apoptosis. Proc. Natl. Acad. Sci. USA 95: 3014-3019

60. Mills JC, Lee VM and Pittman RN (1998) Activation of a PP2A-like phosphatase and dephosphorylation of tau protein characterize onset of the execution phase of apoptosis. J. Cell Sci. 111: 625-636

61. Scherly D, Boelens W, Van Venrooij WJ, Dathan NA, Hamm J and Mattaj IW (1989) Identification of the RNA binding segment of human U1 A protein and definition of its binding site on U1 snRNA. EMBO J. 8: 4163-4170 